\title{
Taxonomy of the Aerobic Pseudomonads: the Properties of the Pseudomonas stutzeri Group
}

\author{
By N. J. PALLERONI, M. DOUDOROFF AND R. Y. STANIER \\ Department of Bacteriology and Immunology, University of California, \\ Berkeley, California 94720, U.S.A.
}

AND R. E. SOLÁNES

Cátedra de Microbiología, Facultad de Ciencias Agrarias, Universidad Nacional de Cuyo, Mendoza, Argentina

AND M. MANDEL

Department of Biology, The University of Texas, M.D. Anderson Hospital and Tumor Institute at Houston, Houston, Texas 77025, U.S.A.

(Accepted for publication 24 October 1969)

SUMMARY

Strains of Pseudomonas stutzeri and related denitrifying bacteria were compared in their phenotypic properties and mean deoxyribonucleic acid (DNA) base composition. On the basis of this comparison and of in vitro DNA hybridization experiments, it was concluded that, using practical diagnostic tests, no more than two nomenspecies can be recognized within the group. One, $P$. stutzeri, was extremely variable in phenotypic characteristics and in DNA base composition; we included in it the strains previously assigned to $P$. stanieri. The other was a new species, $P$. mendocina Palleroni, which was more homogeneous in phenotypic characters, and in DNA base composition and homology. The comparative properties of known denitrifying pseudomonads are tabulated.

\section{INTRODUCTION}

Pseudomonas stutzeri is a non-fluorescent, denitrifying pseudomonad, widely distributed in soil and water. It was discovered and described as Bacillus denitrificans II by Burri \& Stutzer in I 895, and renamed Bacterium stutzeri by Lehmann \& Neumann in $\mathrm{I} 896$. Thereafter, the taxonomic and nomenclatural status of this well-characterized species became confused, and was cleared up by van Niel \& Allen only in 1952, when they retraced the history of the species, and redescribed it. P. stutzeri can be distinguished from other Pseudomonas spp. by many properties, of which the salient ones are: vigorous denitrifying ability; use of starch and maltose as carbon sources; and a characteristic and unusual colony structure; colonies of freshly isolated strains are wrinkled, tough and coherent, and have a light-brown colour which reflects the unusually high cytochrome $c$ content of the cells.

Stanier, Palleroni \& Doudoroff (I966) extended the description of Pseudomonas stutzeri, on the basis of a detailed examination of 17 strains isolated in diagnostic laboratories in Denmark and France from clinical specimens. A concurrent determination of the buoyant densities of DNA from these strains by Mandel (I966) 
revealed a marked bimodal distribution: six strains had a guanine + cytosine (GC) content of about 62 moles $\%$, and II of about 65 moles \%; he assigned the former strains to a new species, $P$. stanieri with strain 224 as holotype, and with the reservation that strains 223, 320 and 228 were atypical and might not belong to the species. He limited P. stutzeri to the strains of the higher GC content. Stanier et al. (I966) found few consistent phenotypic differences between the two groups of strains and they did not accept Mandel's taxonomic proposal. The number of strains examined in this study was relatively small, and the principal source from which they had been isolated (clinical specimens) was certainly atypical, as there is no evidence that these denitrifying bacteria are associated with vertebrates as parasites, pathogens or commensals. It therefore seemed desirable to enlarge the study of these organisms.

Two of us (N. J. Palleroni \& R. E. Solánes) isolated many additional strains of non-fluorescent denitrifying pseudomonads by enrichment procedures from soil and water samples collected in the province of Mendoza, Argentina; most of these strains had the typical distinguishing features of Pseudomonas stutzeri outlined above. However, some failed to attack starch and maltose, and formed smooth colonies on primary isolation. Further study showed that these strains were representatives of a related but readily distinguishable species, which we shall name $P$. mendocina. In this paper, we shall describe the phenotypic and genotypic properties of $P$. mendocina and of the P. stutzeri-P. stanieri complex.

\section{MATERIALS AND METHODS}

Origins of the strains. In addition to the strains described by Stanier et al. (1966) the following new isolates from denitrification enrichment cultures were examined. The source material and the conditions of the enrichment (carbon source and temperature) are indicated for each strain in parenthesis.

Strains assigned to the P.mendocina stutzeri-P. stanieri complex: $\mathrm{CH}$ I9 (soil,

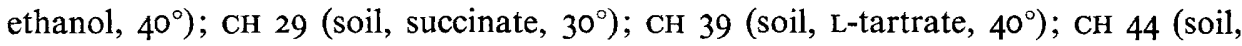
L-tartrate, $30^{\circ}$ ); $\mathbf{C H ~} 48$ (water, sebacate, $30^{\circ}$ ); $\mathrm{CH} 49$ (soil, ethanol, $30^{\circ}$ ); $\mathrm{CH} 52$ (water, ethanol, $30^{\circ}$ ); $\mathrm{CH} 53$ (water, succinate, $30^{\circ}$ ); $\mathrm{CH} 54$ (water, succinate, $30^{\circ}$ ); $\mathrm{CH} 58$ (soil, L-tartrate, $30^{\circ}$ ); $\mathrm{CH} 60$ (water, L-tartrate, $30^{\circ}$ ); $\mathrm{CH} 62$ (soil, L-tartrate, $30^{\circ}$ ); $\mathrm{CH} 63$ (soil, L-tartrate, $30^{\circ}$ ); $\mathrm{CH} 64$ (soil, L-tartrate, $30^{\circ}$ ); $\mathrm{CH} 69$ (water, ethanol, $40^{\circ}$ ); $\mathrm{CH} 70$ (water, ethanol, $40^{\circ}$ ); $\mathrm{CH} 80$ (soil, succinate, $30^{\circ}$ ); $\mathrm{CH} 82$ (water, succinate, $30^{\circ}$ ); $\mathrm{CH} 85$

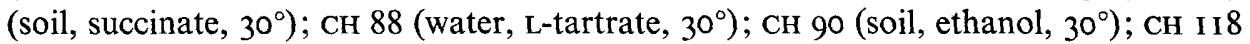
(soil, sebacate, $40^{\circ}$ ).

Strains assigned to Pseudomonas sp. nov.: $\mathrm{CH} 20$ (water, succinate, $40^{\circ}$ ); $\mathrm{CH} 34$ (soil, succinate, $40^{\circ}$ ); $\mathrm{CH} 35$ (soil, L-tartrate, 40); $\mathrm{CH} 50$ (soil, ethanol, $30^{\circ}$ ); $\mathrm{CH} 67$ (water, L-tartrate, $40^{\circ}$ ); $\mathrm{CH} 74$ (water, ethanol, $40^{\circ}$ ); $\mathrm{CH}$ 9I (soil, sebacate, $40^{\circ}$ ); $\mathrm{CH} 95$ (water, ethanol, $30^{\circ}$ ); $\mathrm{CH}$ IIO (soil, ethanol, $40^{\circ}$ ); $\mathrm{CH} \mathrm{II3} \mathrm{(soil,} \mathrm{ethanol,} 40^{\circ}$ ); $\mathrm{CH} \mathrm{I} 20$ (water, sebacate, $40^{\circ}$ ); $\mathrm{CH}$ I 39 (soil, ethanol, $30^{\circ}$ ).

Phenotypic characterization. The phenotypic characterization of the strains was carried out by the methods described by Stanier et al. (I966).

DNA base compositions. DNA was isolated and the base composition determined as described by Mandel (I966).

In vitro DNA hybridizations. Extraction and purification of DNA was by the procedure of Marmur (196I). Radioactive DNA was obtained by addition of ${ }^{14} \mathrm{C}$ adenine 
to a culture in a medium prepared with the standard mineral base described by Stanier et al. (I966), with the addition of $0.2 \%$ (w/v) vitamin-free Casamino acids, and $0.2 \%(\mathrm{w} / \mathrm{v})$ of sodium lactate. Adenine was added 30 to $60 \mathrm{~min}$. (about $\mathrm{I} \cdot 5$ generations) before harvesting the culture, which was grown on a rotary shaker at $30^{\circ}$.

DNA hybridizations in vitro were performed by the technique of Johnson \& Ordal (1968), fully described by Ballard et al. (1970). By this technique, competition with the homologous DNA, rather than direct binding, was determined. The results were expressed as 'per cent competition', i.e. the relative competition obtained in each case compared with the competition with homologous DNA, arbitrarily assigned a value of $100 \%$.

\section{RESULTS}

Isolation of Pseudomonas mendocina from enrichment cultures. The strains of $P$. mendocina described in this paper were isolated from water and soil by enrichment cultures with different carbon sources, either at 30 or $40^{\circ}$. Nine of the twelve isolates were from enrichments at $40^{\circ}$; in seven the same inocula yyielded $P$. stutzeri when incubated at $30^{\circ}$, with the same carbon source.

Table I. Pseudomonas stutzeri-P. stanieri complex. Substrates used by $90 \%$ or more of the strains

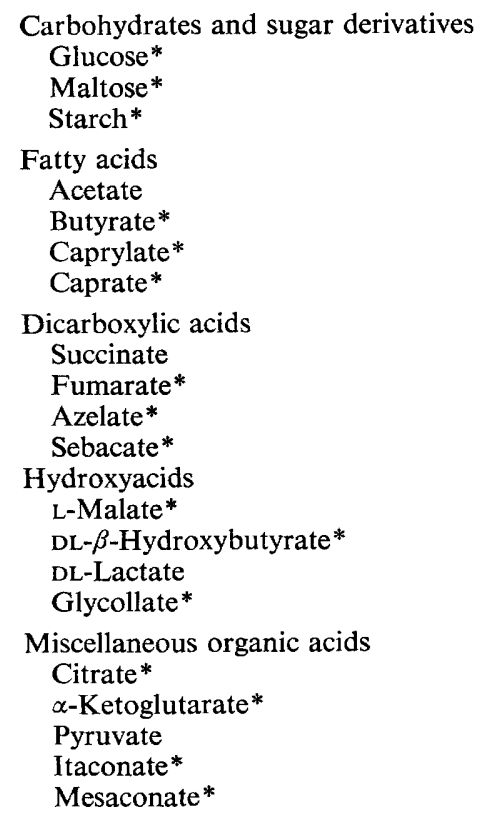
Polyalcohols and glycols Glycerol* Ethylene glycol Propylene glycol*
Alcohols Ethanol*

Non-nitrogenous aromatic and other cyclic compounds (None)

Aliphatic amino acids L- $\alpha$-Alanine* D- $\alpha$-Alanine* L-Leucine* L-Glutamate*

Amino acids and related compounds containing a ring structure L-Proline*

Amines

(None)

Miscellaneous nitrogenous compounds (None)

Paraffin hydrocarbons (None)

* Substrates not used by all strains. Negative strains are listed in Table 2 .

Common properties of the stutzeri group. It may be useful to summarize the properties shared by the Pseudomonas stutzeri-P. stanieri complex and $P$. mendocina n.sp., and indicate those characters that set them apart from other major species groups among the aerobic pseudomonads.

The members of this group were similar in structure. The rod-shaped bacteria were 
Table 2. Pseudomonas stutzeri-P. stanieri complex. Substrates used by a fraction of the strains

Substrate

Xylose

L-Arabinose

Glucose

Mannose

Fructose

Maltose

Starch

Gluconate

Saccharate

Mucate

Propionate

Butyrate

Isobutyrate

Valerate

Isovalerate

Caproate

Heptanoate

Caprylate

Pelargonate

Caprate

Malonate

Fumarate

Glutarate

Adipate

Pimelate

Suberate

Azelate

Sebacate

D-Malate

L-Malate

L(+)Tartrate

M-Tartrate

DL- $\beta$-Hydroxybutyrate

Glycollate

Glycerate

Hydroxymethylglutarate

Citrate

$\alpha$-Ketoglutarate

Aconitate

Levulinate

Itaconate

Mesaconate
Total of strains

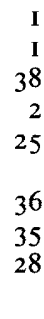

Negative strains

All except $\mathrm{CH} 85$

All except $\mathrm{CH} 85$

CH 62

All except 275, CH 85

$223,225,275,316,319,419$, CH I9, CH 48, CH 52,

CH 53, CH 54, $\mathrm{CH} \mathrm{62,} \mathrm{CH} \mathrm{80,} \mathrm{and} \mathrm{CH} 82$

229, 316, СН 62

$275,229,316$, CH 62

$228,319,320,32 \mathrm{I}, 419, \mathrm{CH} 29, \mathrm{CH} 53$, СH 54, $\mathrm{CH} 62, \mathrm{CH} 8 \mathrm{O}$ and $\mathrm{CH} 82$

$220,221,224,225,226,227,275,316,319,419$, CH 19, CH 53, CH 54 and $\mathrm{CH}$ I I 8

All except 222, 223, 228, 229, 318, 230, 32 I,

CH 39, CH 52, CH 58, СH 62, СH 63, СH 64, СH 69. CH $70, \mathrm{CH} 85, \mathrm{CH} 88$ and $\mathrm{CH} 90$

220, 223, 224, 225, 228, 275, 3I 9, 320, 32 I, 4I 9, CH 49, CH 52, CH 58, CH 88 and $\mathrm{CH} 90$

275 , $\mathrm{CH} 29, \mathrm{CH} 58, \mathrm{CH} 60$

All except $\mathrm{CH} 53, \mathrm{CH} 70$ and $\mathrm{CH} 80$

$220,229,275,318,32$ I 4 I 9, CH 29, CH 49, CH 52, CH 58 and $\mathrm{CH} 63$

$275,320,321, \mathrm{CH} \mathrm{29,} \mathrm{CH} \mathrm{49,} \mathrm{CH} \mathrm{52,} \mathrm{CH} \mathrm{60,} \mathrm{СH} \mathrm{62,}$ $\mathrm{CH} 90$ and $\mathrm{CH} 1 \mathrm{I} 8$

$275,320,32 \mathrm{I}, \mathrm{CH} 29, \mathrm{CH} 49, \mathrm{CH} 52, \mathrm{CH} 58, \mathrm{CH} 62$ and $\mathrm{CH} 90$

223, $\mathrm{CH} 29, \mathrm{CH} 49, \mathrm{CH} 58$ and $\mathrm{CH} 60$

$\mathrm{CH} 29, \mathrm{CH} 60$ and $\mathrm{CH} 62$

223, $\mathrm{CH} 29, \mathrm{CH} 49, \mathrm{CH} 52, \mathrm{CH} 60$ and $\mathrm{CH} 90$

CH 60, CH 64, CH 70, CH 85

$228,229,320,32 \mathrm{I}, 4 \mathrm{I} 9$ and $\mathrm{CH} 58$

$\mathrm{CH} 49$ and $\mathrm{CH} 60$

$228, \mathrm{CH} 29, \mathrm{CH} 44, \mathrm{CH} 49, \mathrm{CH} 52, \mathrm{CH} 58$ and $\mathrm{CH} 60$

All except 223, $\mathrm{CH} 44, \mathrm{CH} 58$ and $\mathrm{CH} 85$

All except $\mathrm{CH} 58$

All except 223 and $\mathrm{CH} 85$

$228,229,275$ and 419

275 and 419

All except 228, 3I 6, 320 and 32 I

CH 19 and $\mathrm{CH} 48$

All except 419 and $\mathrm{CH} 85$

All except $\mathrm{CH} 85$

CH 29, $\mathrm{CH} 49, \mathrm{CH} 53$ and $\mathrm{CH} 62$

CH 29, $\mathrm{CH} 44, \mathrm{CH} 58$ and $\mathrm{CH} 60$

All except 223, 275, 3I9, 320, 32 I, 4I9, CH I9,

CH $48, \mathrm{CH} 52, \mathrm{CH} 58, \mathrm{CH} 63, \mathrm{CH} 69, \mathrm{CH} 70, \mathrm{CH} 80$, $\mathrm{CH} 82$ and $\mathrm{CH} 85$

All except 222, 226, 227 and $\mathrm{CH}_{48}$

3 I 8

228 and $\mathrm{CH} 29$

All except 220, 22I, 223, 224, 225, 228, 275, 316, $319,320,321,419, \mathrm{CH} 48, \mathrm{CH} 69, \mathrm{CH} 70$, СH 80 , CH 82 and $\mathrm{CH}$ I 8

All except $\mathrm{CH} 48$ and $\mathrm{CH} 60$

223 and $\mathrm{CH} 62$

223 and $\mathrm{CH}_{62}$ 
Table 2 (cont.)

Total of
positive

Mannitol
Glycerol
Propylene glycol
2,3-Butylene glycol
Ethanol
Propanol
Butanol
Isobutanol
D-Mandelate
L-Mandelate
Benzoyl formate
Benzoate

p-Hydroxybenzoate

Quinate

Glycine

L- $\alpha$-Alanine

$D-\alpha$-Alanine

$\beta$-Alanine

L-Serine

L-Leucine

L-Isoleucine

L-Valine

L-Aspartate

L-Glutamate

$\alpha$-Amino-butyrate

$\delta$-Amino-valerate

L-Histidine
L-Proline
L-Tyrosine
L-Phenylalanine

Kynurenate

Ethanolamine

Putrescine

Spermine

Betaine

Sarcosine

Nicotinate

Trigonelline strains

24

38

35

34

36

34

3 I

3 I

I

I

29

6

I

34

37

35

3

4

38

34

33

27

37

25

2 I

37

34

9

2

8

29

8

3

I

I

I
Negative strains

$226,227,316,318,319,320,321,419$, СH 19, CH 48, CH 53, CH 54, CH 80, CH 82 and $\mathrm{CH}$ I I 8 275

$22 \mathrm{I}, \mathrm{CH} \mathrm{53,} \mathrm{CH} 54$ and $\mathrm{CH} 60$ $226,227,229,275$ and $\mathrm{CH} 48$ CH 53, $\mathrm{CH} 54$ and $\mathrm{CH} 60$ $22 \mathrm{I}, \mathrm{CH} 53, \mathrm{CH} \mathrm{54,} \mathrm{CH} 60$ and $\mathrm{CH} 64$ $275, \mathrm{CH} 49, \mathrm{CH} 53, \mathrm{CH} 54, \mathrm{CH} 58, \mathrm{CH} 60, \mathrm{CH} 62$, and $\mathrm{CH} 64$

$226,227,229,275,320,32 \mathrm{I}, \mathrm{CH} 58$ and $\mathrm{CH} 60$

All except $\mathrm{CH} 88$

All except $\mathrm{CH} 88$

All except $\mathrm{CH} 88$

$220,22 \mathrm{I}, 223,224,225,275,3 \mathrm{I} 8,320,32 \mathrm{I}$ and CH 85

All except 226, 227, 318, 419, $\mathrm{CH} 69$ and $\mathrm{CH} 85$ All except $\mathrm{CH} 48$

CH 29, CH 49, CH 58, CH 60 and $\mathrm{CH} 90$

CH 49 and $\mathrm{CH}_{60}$

$\mathrm{CH} \mathrm{29,} \mathrm{CH} 44, \mathrm{CH} 60$ and $\mathrm{CH} 62$

All except $\mathrm{CH} \mathrm{48,} \mathrm{CH} 69$ and $\mathrm{CH} 70$

All except $\mathrm{CH} 48, \mathrm{CH} 69, \mathrm{CH} 80$ and $\mathrm{CH} 82$

CH 60

$275,319,419, \mathrm{CH} 60$ and $\mathrm{CH} 62$

$228,229,275, \mathrm{CH} 39, \mathrm{CH} 49$ and $\mathrm{CH} 60$

$221,229,275,419, \mathrm{CH}$ I9, CH 39, CH 53, CH 54, $\mathrm{CH} 62, \mathrm{CH} 69, \mathrm{CH} 88$ and $\mathrm{CH} 90$

CH 49 and $\mathrm{CH} 60$

220, 221, 222, 224, 225, 228, 275, 3I6, 3I 8, 320, $32 \mathrm{I}, \mathrm{CH} 19, \mathrm{CH} 29$ and $\mathrm{CH} 62$

221, 222, 223, 224, 225, 228, 229, 275, 316, 320, $32 \mathrm{I}, \mathrm{CH}$ I9, CH 29, CH 44, CH 52, CH 60, CH 88 and $\mathrm{CH}$ I I 8

All except $\mathrm{CH} 85$

419 and $\mathrm{CH} 62$

223, 229, 318, $\mathrm{CH} 29$ and $\mathrm{CH} 60$

All except 223, 275, 319, $\mathrm{CH} 19, \mathrm{CH} 48, \mathrm{CH} 70$, CH $80, \mathrm{CH} 82$ and $\mathrm{CH} 85$

All except 316 and 319

All except 220, 22I, 224, 225, 316, 319, 320 and 32 I 229, 316, 419, СH 44, СH 49, СH 53, СH 58, СH 60, $\mathrm{CH} 90$ and $\mathrm{CH}$ I 8

All except 319, 320, $32 \mathrm{I}, \mathrm{CH} \mathrm{48,} \mathrm{CH} 69$, $\mathrm{CH} 70$, CH 80 and $\mathrm{CH} 82$

All except 223, $\mathrm{CH} 48$ and $\mathrm{CH} 85$

All except $\mathrm{CH} 48$

All except 319

All except 319

0.75 to $0.85 \mu \mathrm{m}$. wide and $\mathrm{I} \cdot 4$ to $2 \cdot 8 \mu \mathrm{m}$. long in exponentially growing cultures. All bore a single polar or subpolar flagellum with a wavelength of $1 \cdot 75$ to $2 \cdot 0 \mu \mathrm{m}$. (Pl. I). In several strains of Pseudomonas mendocina (notably $\mathrm{CH} 39$, IIO and I20), lateral flagella of shorter wavelength (about I $\mu \mathrm{m}$.) (Pl. 2) were also produced, particularly in young cultures on complex solid media. Two of ten strains of P. stutzeri (227 and 
319) also had lateral flagella of short wavelength, although they occurred on fewer bacteria than in P. mendocina. In this group, the flagella of shorter wavelength were easily shed during the manipulations of flagella staining.

No member of the stutzeri group accumulated poly- $\beta$-hydroxybutyrate as a reserve material. Neither fluorescent nor phenazine pigments were produced. Growth factors were not required. A fairly wide, though variable, range of simple organic compounds could serve as sole sources of carbon and energy; the most distinctive substrates, which supported growth of nearly all strains of the group, but were rarely used by other Pseudomonas species, were ethylene glycol and glycollic acid. All strains grew well under anaerobic conditions, with abundant gas production, in media that contained sufficient nitrate. It was noted that the capacity for vigorous denitrification might be lost after prolonged cultivation of strains on nitrate-free media, and a period of adaptation might be required to restore this activity to a high level (Stanier et al. I966). The temperature range was relatively large; all strains grew well at $40^{\circ}$, and none grew at $4^{\circ}$.

Phenotypic properties of newly isolated strains assigned to the Pseudomonas stutzeri$P$. stanieri complex. Twenty-two strains of $P$. stutzeri from soil and water in Argentina isolated by enrichment techniques for denitrifying bacteria were characterized, and some of the nutritional properties of the strains previously examined (Stanier et al. 1966) were rechecked. The nutritional spectrum of all 39 strains is shown in Tables I and 2. The nutritional variability of the complex, evident from earlier work, became even clearer. Although 29 compounds among those tested could be utilized by $90 \%$ or more of the strains, only acetate, succinate, lactate, pyruvate and ethylene glycol were universal substrates (Table I). Glucose, caprylate, caprate, fumarate, L-malate, glycollate, ethanol, L- and D-alanine and glutamate, universally used by the I 7 strains studied by Stanier et al. (1966), were not attacked by some of the strains isolated in Argentina.

Phenotypic properties of Pseudomonas mendocina Palleroni sp.nov. Colonies were flat, smooth, butyrous, of brownish yellow colour. The wrinkled appearance of freshly isolated colonies of $P$. stutzeri was not observed. The yellow colour was due to the presence of carotenoid pigments in the cells.

Starch, gelatin and poly- $\beta$-hydroxybutyrate were not hydrolysed and the egg-yolk reactions were negative. All strains were arginine dihydrolase positive. Strains that grew with benzoate or $p$-hydroxybenzoate attacked the respective diphenolic intermediates (catechol and protocatechuate) by ortho cleavage, and therefore degraded aromatic substrates through the $\beta$-ketoadipate pathway. The temperature optimum was about $37^{\circ}$; all strains could grow at $4 \mathrm{I}^{\circ}$, and none at $4^{\circ}$.

The nutritional spectrum of Pseudomonas mendocina is described in Tables 3 and 4. In nutrition, the species was far more homogeneous than the $P$. stutzeri-P. stanier $i$ complex. Of the 67 compounds that can be used by the species as a whole, 46 were used by all twelve strains and 55 by at least eleven strains. The species differed from $P$. stutzeri in many nutritional respects; it failed to use starch, maltose, azelate and sebacate, used by most strains of $P$. stutzeri; it grew with spermine, betaine, sarcosine and geraniol, rarely used by strains of $P$. stutzeri. In nutrition, and in the possession of arginine dihydrolase, $P$. mendocina resembled species of the fluorescent group, particularly $P$. aeruginosa. Properties shared by these two species included: polar monotrichous flagella, denitrifying ability, capacity for growth at $4 I^{\circ}$, and ability to 
use geraniol, an alcohol not attacked by other Pseudomonas spp. Pseudomonas mendocina and $P$. aeruginosa could, however, be readily distinguished from one another by differences in pigmentation, in attack on mannitol, azelate and suberate, and in gelatinase production.

Table 3. Pseudomonas mendocina. Substrates utilized by $90 \%$ or more of the strains

Carbohydrates and sugar derivatives
D-Glucose
Gluconate
Saccharate
Mucate*
Fatty acids
Acetate
Propionate
Butyrate
Valerate
Isovalerate*
Caproate*
Heptanoate
Caprylate
Pelargonate
Caprate
Dicarboxylic acids
Malonate
Succinate
Fumarate
Glutarate
Hydroxyacids
DL- $\beta$-Hydroxybutyrate
DL-Lactate
Glycollate
DL-Glycerate*
Miscellaneous organic acids
Citrate
$\propto-$ Ketoglutarate
Aconitate
Levulinate*
Itaconate*
Mesaconate
Polyalcohols and glycols
Ethylene glycol*
Propylene glycol

\section{Alcohols \\ Ethanol \\ Propanol \\ n-Butanol \\ Isobutanol \\ Geraniol}

Non-nitrogenous aromatic and other cyclic compounds Quinate*

Aliphatic aminoacids

L- $\alpha$-Alanine

D- $\alpha$-Alanine

$\beta$-Alanine*

L-Serine

L-Leucine

L-Isoleucine

L-Valine

L-Aspartate

L-Glutamate

DL-Arginine

$\alpha$-Aminobutyrate

$\alpha$-Aminovalerate

Aminoacids and related compounds having a ring structure

L-Histidine

L-Proline

L-Tyrosine

Amines

Putrescine

Spermine

Miscellaneous nitrogenous compounds

Betaine

Sarcosine

Paraffinic hydrocarbons

(None)

* Substrates not used by all strains. Negative strains are listed in Table 4 .

Nutritional characters common to the two species of the stutzeri group, but rarely if ever encountered in species of the fluorescent group, included the ability to use ethylene glycol and glycollate, and the failure to use 2-ketogluconate.

DNA base composition of the stutzeri group. DNA base compositions were determined from buoyant density measurements for many of the strains isolated in Argentina (Table 5). The mean base composition of the DNA of Pseudomonas mendocina showed little variation from strain to strain; all values clustered closely around $63 \cdot 2$ moles $\%$ GC. However, values for the remaining 22 newly isolated strains ranged from $62 \cdot 2$ to 66.3 mole $\%$ GC; the distribution of values for the individual strains was about Gaussian, with a peak of $64: 3 \%$ GC (Fig. I). When these data were combined with the 
Table 4. Pseudomonas mendocina. Substrates utilized by a fraction of the strains

Substrate

D-Fructose

Mucate

Isobutyrate

Isovalerate

Caproate

D-Malate

L- $(+)$-Tartrate

DL-Glycerate

Hydroxymethylglutarate

Pyruvate

Levulinate

Citraconate

Itaconate

Glycerol

Ethylene glycol

Benzoate

Quinate

Glycine

$\beta$-Alanine

L-Phenylalanine

Tryptamine

\section{Total of positive} strains

9

I I

7

I I

I I

5

5

I I

9

IO

I I

IO

I I

9

II

IO

I I

IO

I I

5
Negative strains

CH 20, CH 34, CH 110

CH 95

$\mathrm{CH} 20, \mathrm{CH} 34, \mathrm{CH} \mathrm{35,} \mathrm{CH} 50$ and $\mathrm{CH} 67$

CH 95

$\mathrm{CH} 95$

All except $\mathrm{CH} 20, \mathrm{CH} 34, \mathrm{CH} 35, \mathrm{CH} 50$ and $\mathrm{CH} 67$

All except $\mathrm{CH} 35, \mathrm{CH} \mathrm{67,} \mathrm{CH} 95, \mathrm{CH}$ I 10 and $\mathrm{CH}$ I 39

CH 95

CH 34, $\mathrm{CH} 50$ and $\mathrm{CH} 95$

CH 91 and $\mathrm{CH} 95$

CH 91

$\mathrm{CH} 20$ and $\mathrm{CH} 120$

$\mathrm{CH} 95$

CH 91, CH 95 and $\mathrm{CH} 120$

CH 95

$\mathrm{CH} 74$ and $\mathrm{CH} \mathrm{IIO}$

CH 67

CH 9 I and $\mathrm{CH} 95$

CH 9 I

All except $\mathrm{CH} 20, \mathrm{CH} 34, \mathrm{CH} 35, \mathrm{CH} 50$ and $\mathrm{CH} 67$ $\mathrm{CH} 74, \mathrm{CH} \mathrm{IIO}$ and $\mathrm{CH}$ II 3

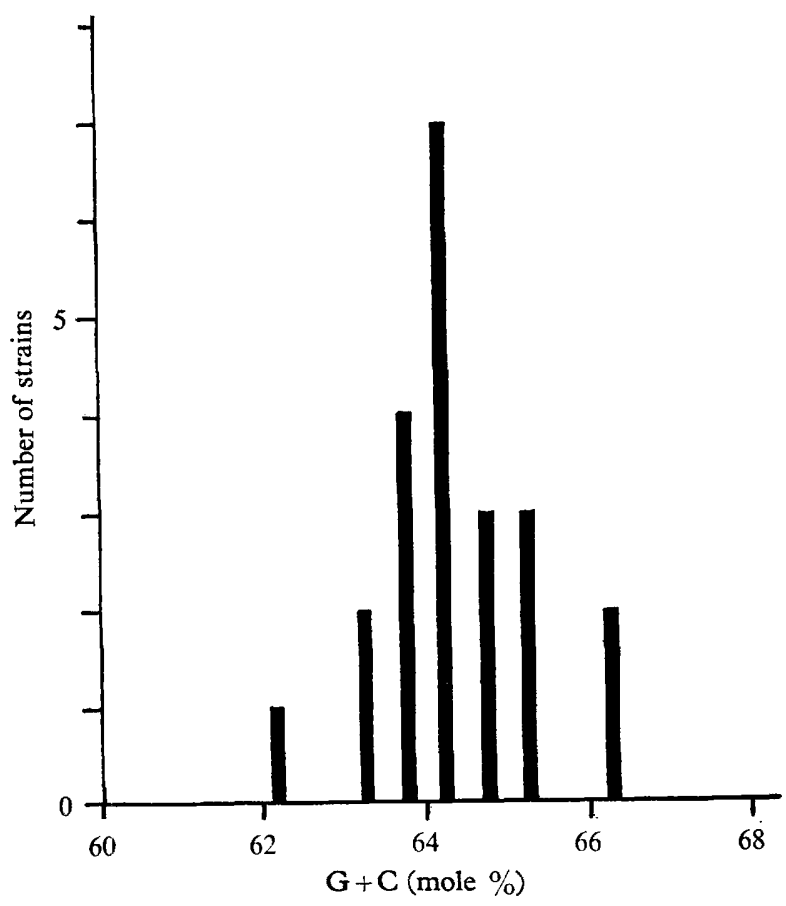

Fig. I. Distribution of guanine + cytosine values (mole \%) among the strains of Pseudomonas stutzeri isolated in Argentina. 
data of Mandel (I966) on the 17 strains of P. stutzeri studied by Stanier et al. (1966), the bimodal distribution of GC values which then led Mandel to propose a separation into two species remained, but was less clear-cut (Fig. 2). The majority of values clustered between $64 \cdot 3$ and $65 \cdot 3$ mole $\%$ GC; there was still a minor peak at $62 \cdot 2$, but it was now connected by intervening values to the major peak. There is little probability that these values can be fitted to a single Gaussian distribution on the assumption that the standard deviation of the values is about $\mathrm{I} \% \mathrm{GC}$, that is, no greater than that

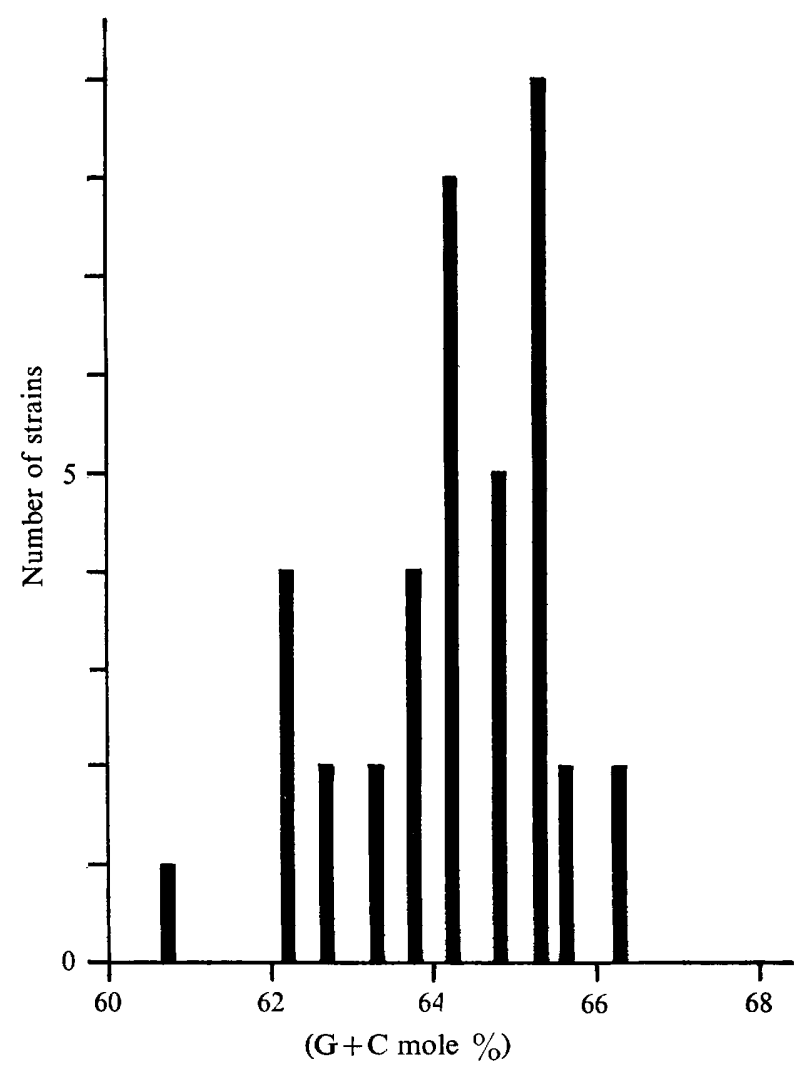

Fig. 2. Distribution of guanine + cytosine values (mole \%) among all the strains of Pseudomonas stutzeri described in this paper.

found for other Pseudomonas species (Mandel, 1966). The extreme limits of base composition were represented by one strain with a value of $60.6 \mathrm{~mole} \% \mathrm{GC}$, and two with 66.3. Mandel's (1966) data for other Pseudomonas species in which the DNA base composition of many strains had been determined, showed that well-characterized species generally had a remarkably constant mean base composition. The wide variation in the DNA base composition of the $P$. stutzeri-P. stanieri complex was exceptional among aerobic pseudomonads, although a comparable situation occurred in the Acinetobacter group (Baumann, Doudoroff \& Stanier, 1968). The variation in GC content may be related to the very high degree of nutritional heterogeneity in the strains of this complex (see Table 2). 
In vitro DNA hybridization in the stutzeri group. To obtain a further insight into the genotypic structure of the stutzeri group, we performed experiments on in vitro DNA hybridization, using several reference strains of the Pseudomonas stutzeri-P. stanieri complex, with different DNA base compositions, and one reference strain of $P$. mendocina. In most competition experiments, annealing temperatures of 70 to $72^{\circ}$ (about $25^{\circ}$ below the $T m$ of the DNA samples being compared) were used. A few competition

Table 5. CsCl buoyant densities* and calculated GC (mole \%) in the DNA of strains of the stutzeri group isolated in Argentina

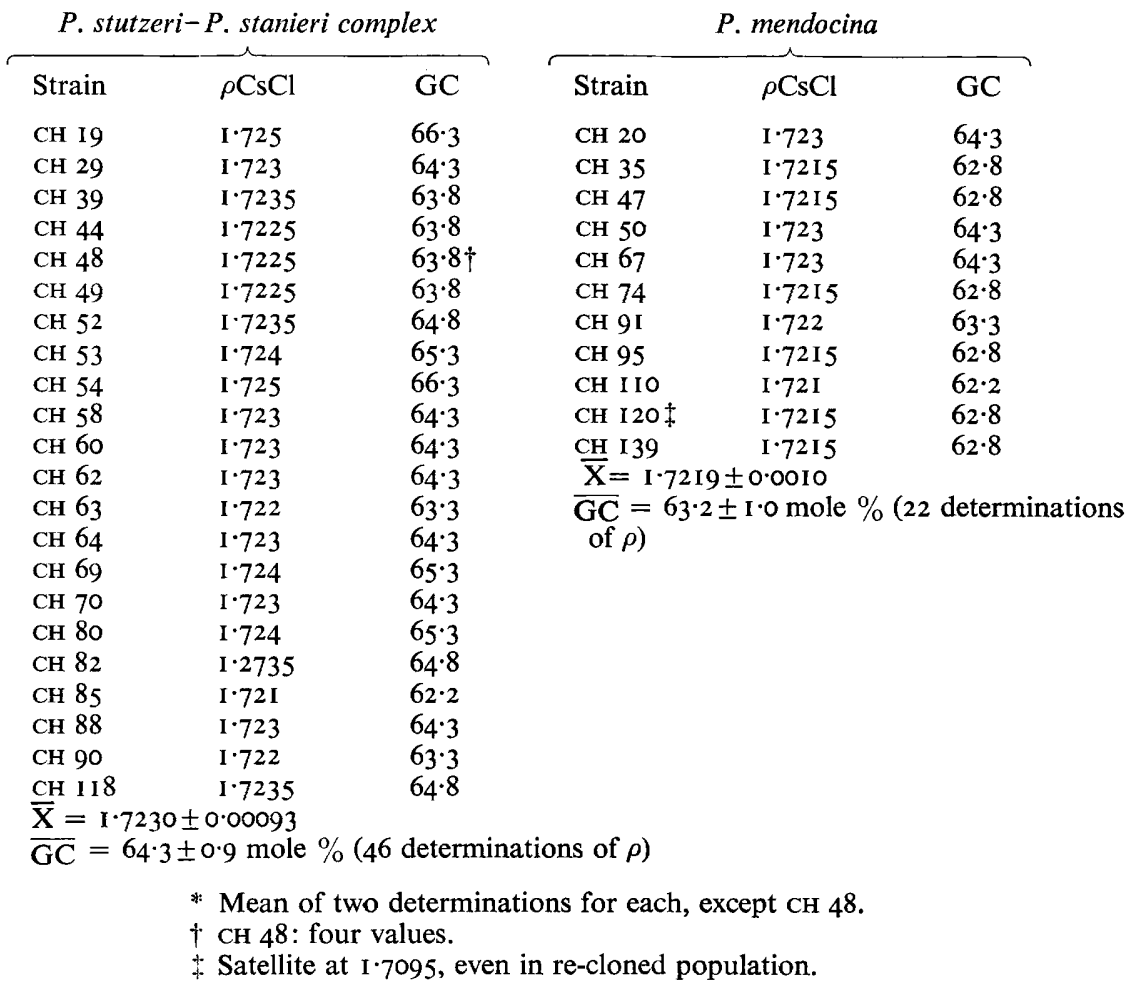

experiments were also made at a higher annealing temperature $\left(80^{\circ}\right)$, where conditions for DNA-DNA hybridization were much more stringent; the occurrence of detectable competition at this annealing temperature probably indicated some virtually complete base sequence homologies between the two organisms.

As one of our goals was to assess the genetic significance of the variable DNA base composition of the Pseudomonas stutzeri-P. stanieri complex, reference DNA was prepared from five strains: three $(220,224$ and 320$)$ had DNA containing about 62 mole \% GC, and two (22I and 222) had DNA of about 65 mole \% GC. In preliminary experiments, the homology of one reference strain from each group was determined with strains of $P$. mendocina, $P$. aeruginosa, $P$. fluorescens (denitrifying biotypes), $P$. putida, $P$. acidovorans and $P$. testosteroni. These experiments (Table 6 ) revealed that the $P$. stutzeri-P. staniericomplex was genetically well isolated from other species of the genus Pseudomonas, with the exception of $P$. mendocina. At an annealing 
temperature of 70 to $72^{\circ}$, competition by DNAs from all species except $P$. mendocina was less than $20 \%$, whereas competition by DNA of $P$. mendocina ranged from 20 to $40 \%$.

Competition at an annealing temperature of 70 or $72^{\circ}$ among DNA preparations from strains studied by Stanier et al. (1966) and Mandel (1966) is shown in Table 7. Strains could be subdivided into four groups in terms of GC content and their relative

Table 6. DNA competition among strains of the Pseudomonas stutzeri group and other species of aerobic pseudomonads*

\begin{tabular}{|c|c|c|}
\hline \multirow[b]{2}{*}{ DNA competition within the $P$. stutzeri group } & \multicolumn{2}{|c|}{$\begin{array}{c}\text { Range of } \% \text { DNA com- } \\
\text { petition at }\end{array}$} \\
\hline & $70-72^{\circ}$ & $80^{\circ}$ \\
\hline$P$. stanieri v. $P$. stanieri & $8 I-100$ & $76-92$ \\
\hline$P$. stutzeri v. $P$. stutzeri & $8 I-92$ & $7 I-83$ \\
\hline$P$. stanieri v. $P$. stutzeri & $52-70$ & $30-56$ \\
\hline$P$. mendocina v. $P$. mendocina & $98-100$ & $85-95$ \\
\hline$P$. mendocina v. $P$. stanieri & $19-38$ & $7-9$ \\
\hline$P$. mendocina v. $P$. stutzeri & $28-40$ & 13 \\
\hline $\begin{array}{l}\text { DNA competition between the } P \text {. stutzeri } \\
\text { group and other Pseudomonas spp. }\end{array}$ & & \\
\hline$P$. stanieri $(220,224)$ v. $P$. aeruginosa $(52)$ & $0-18$ & \\
\hline P. stanieri $(\overline{220,224)}$ v. P. putida $(90)$ & $0-4$ & \\
\hline$P$. stanieri $(224)$ v. P. fluorescens $(2,50)$ & $0-7$ & \\
\hline P. stanieri $(\overline{224})$ v. P. acidovorans (105) & 0 & \\
\hline P. stanieri $(\overline{224)}$ v. $P$. testosteroni $(78)$ & 0 & \\
\hline$P$. stutzeri $(\overline{22 \mathrm{I}}, 222)$ v. $P$. aeruginosa $(52)$ & $0-5$ & \\
\hline P. stutzeri $(\overline{22 \mathrm{I}, 222)}$ v. P. putida $(90)$ & $0-8$ & \\
\hline P. stutzeri $\overline{(221,222)}$ v. P. fluorescens $(2,50)$ & $0-3$ & \\
\hline P. stutzeri (221) v. P. acidovorans (105) & 0 & \\
\hline P. stutzeri $(\overline{221})$ v. P. testosteroni $(78)$ & 0 & \\
\hline$P$. mendocina $(\mathrm{CH} 20)$ v. $P$. aeruginosa $(52)$ & 9 & \\
\hline P. mendocina $(\overline{\mathrm{CH} 20})$ v. P. fluorescens $(2,50)$ & I8-I9 & \\
\hline P. mendocina $(\overline{\mathrm{CH} \mathrm{20}})$ v. P. fluorescens (3I) & $2 \mathbf{I}$ & \\
\hline P. mendocina $(\overline{\mathrm{CH} 2 \mathrm{O}})$ v. P. fuorescens $(83)$ & $2 I$ & \\
\hline$P$. mendocina $(\overline{\mathrm{CH} 20})$ v. $P$. acidovorans (I4) & 0 & \\
\hline$P$. mendocina $(\mathrm{CH} 20)$ v. P. testosteroni $(\overline{78})$ & 0 & \\
\hline
\end{tabular}

* Values for homologous DNA ( $100 \%$ ) are not included. The data for competition within the $P$. stutzeri group are collected from Tables 7,8 and Io. For all other DNA competition experiments, the strain numbers are shown in parentheses, with the reference underlined.

and absolute competitions with high and low GC reference strains. Five low GC strains (group I) showed consistently high homology (80 to $100 \%$ competition) with the low GC reference strains, and a lower homology ( 58 to $78 \%$ competition) with the high GC reference strains. Six high GC strains (group II) showed the inverse pattern of homology. Repetition of some experiments at an annealing temperature of $80^{\circ}$ gave essentially similar results (Table 8). The strains of groups I and II appear to constitute two intraspecific clusters, each characterized by comparatively high internal genetic homology. However, the correlations between GC content and genetic homology were by no means perfect. Five strains, one of low GC content (group III) and four of high GC content (group IV) showed relatively low competition values ( 20 to $65 \%$ ) 
Table 7. Percentage DNA competition among strains of the Pseudomonas stutzeri$P$. stanieri complex (annealing temperature: 70 or $72^{\circ}$ )

\begin{tabular}{|c|c|c|c|c|c|c|c|}
\hline \multirow[b]{2}{*}{ Group } & \multirow{2}{*}{$\begin{array}{l}\text { Mean DNA } \\
\text { base } \\
\text { composition } \\
\text { mole \% GC }\end{array}$} & \multirow{2}{*}{$\begin{array}{l}\text { Competitor } \\
\text { DNA } \\
\text { strain } \\
\text { number }\end{array}$} & \multicolumn{5}{|c|}{ Reference DNA strain number } \\
\hline & & & 220 & 224 & 320 & $22 \mathrm{I}$ & 222 \\
\hline I & $\begin{array}{l}62 \cdot 2 \\
62 \cdot 2 \\
62 \cdot 7 \\
62 \cdot 7 \\
62 \cdot 2\end{array}$ & $\begin{array}{l}220 \\
224 \\
225 \\
228 \\
320\end{array}$ & $\begin{array}{r}- \\
100 \\
90 \\
83 \\
81\end{array}$ & $\begin{array}{r}100 \\
90 \\
86 \\
83\end{array}$ & $\begin{array}{l}81 \\
81 \\
82 \\
84 \\
-\end{array}$ & $\begin{array}{l}68 \\
60 \\
68 \\
70 \\
70\end{array}$ & $\begin{array}{l}58 \\
61 \\
59 \\
63 \\
64\end{array}$ \\
\hline II & $\begin{array}{l}65 \cdot 2 \\
64 \cdot 7 \\
64 \cdot 7 \\
65 \cdot 5 \\
65 \cdot 2 \\
65 \cdot 2\end{array}$ & $\begin{array}{l}22 \mathrm{I} \\
222 \\
226 \\
227 \\
318 \\
32 \mathrm{I}\end{array}$ & $\begin{array}{l}60 \\
64 \\
67 \\
64 \\
52 \\
61\end{array}$ & $\begin{array}{l}64 \\
57 \\
57 \\
60 \\
59 \\
60\end{array}$ & $\begin{array}{l}60 \\
60 \\
60 \\
65 \\
62 \\
68\end{array}$ & $\begin{array}{l}\overline{86} \\
88 \\
80 \\
89 \\
92\end{array}$ & $\begin{array}{l}81 \\
83 \\
83 \\
87 \\
86\end{array}$ \\
\hline III & $60 \cdot 7$ & 223 & 33 & 35 & 32 & 33 & 37 \\
\hline IV & $\begin{array}{l}64 \cdot 2 \\
65 \cdot 7 \\
65 \cdot 2 \\
65 \cdot 2\end{array}$ & $\begin{array}{l}275 \\
316 \\
319 \\
419\end{array}$ & $\begin{array}{l}20 \\
31 \\
46 \\
33\end{array}$ & $\begin{array}{l}38 \\
49 \\
35 \\
31\end{array}$ & $\begin{array}{l}47 \\
34 \\
33 \\
44\end{array}$ & $\begin{array}{l}29 \\
65 \\
49 \\
56\end{array}$ & $\begin{array}{l}36 \\
47 \\
49 \\
50\end{array}$ \\
\hline
\end{tabular}

Table 8. DNA competition among strains of the Pseudomonas stutzeri-P. stanieri complex (annealing temperature: $80^{\circ}$ )

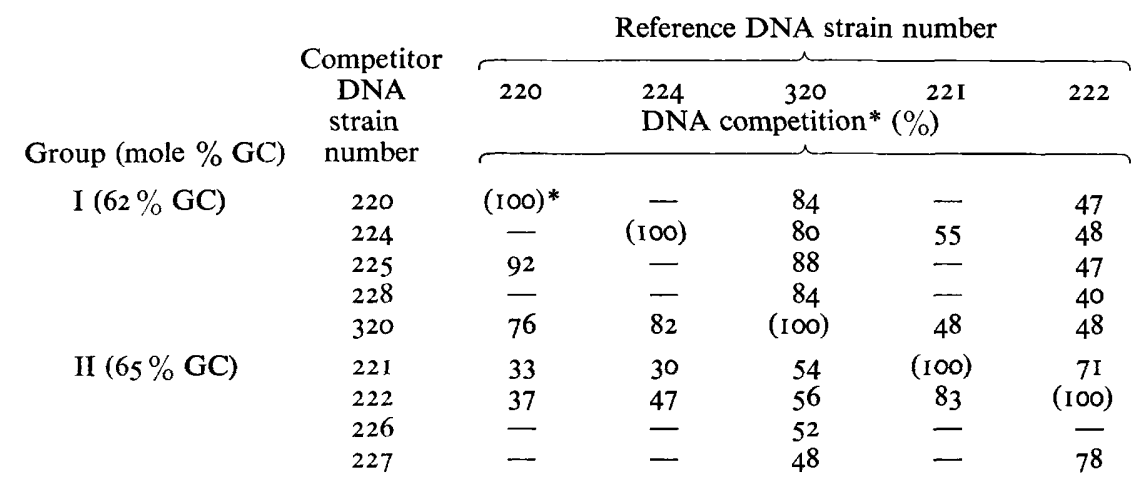

* Figures in parentheses are control values for homologous DNA.

Table 9. DNA competition between strains of the Pseudomonas stutzeri-P. stanieri complex of the $\mathrm{CH}$ series, and strains of $P$. stanieri and P. stutzeri

DNA competition with reference

\begin{tabular}{lccc} 
& & \multicolumn{2}{c}{$\begin{array}{c}\text { DNA competition with reference } \\
\text { strain }(\%)\end{array}$} \\
Strain & $\%$ GC & $\overbrace{224(62 \cdot 2 \%}$ GC) & $222(64 \cdot 7 \%$ GC) \\
CH 63 & $63 \cdot 3$ & 57 & 77 \\
CH 39 & $63 \cdot 9$ & 64 & 75 \\
CH 48 & $64 \cdot 3$ & 60 & 74 \\
CH 54 & $66 \cdot 3$ & 45 & 62
\end{tabular}


with all the reference strains; and in most of these cases, the values obtained with reference strains of similar GC content were not significantly or consistently greater than the values obtained with reference strains of markedly different GC content. It should be noted that these five strains $(223,275,316,3$ I 9 and 4I9) are also aberrant in nutritional respects (Table 2). This analysis accordingly showed that the strains of high GC and of low GC content studied by Stanier et al. (I966) were genetically heterogeneous.

Reference DNAs from strains 222 (high GC) and 224 (low GC) were tested at an annealing temperature of 70 or $72^{\circ}$ with DNA preparations from five strains of the Pseudomonas stutzeri-P. stanieri complex isolated in Argentina, selected for differences in GC content. The competition data are summarized in Table 9; the test strains are arranged in order of increasing GC content, but the clusters of strains that constitute groups I and II do not stand out sharply. In vitro hybridization data accordingly suggest that there may be considerable genetic homology among all strains of the complex, overlain by a substantial amount of genetic variation. The mean DNA base composition of a given strain is therefore not necessarily indicative of its genetic relatedness to other strains of the complex.

Table 10. DNA competition between strains of the Pseudomonas stutzeri group and $P$. mendocina $\mathrm{CH} 20$ (annealing temperature: $70^{\circ}$ )

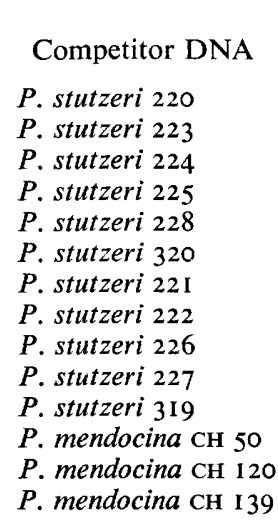

$\% \mathrm{GC}$
$62 \cdot 2$
$60 \cdot 7$
$62 \cdot 2$
$62 \cdot 7$
$62 \cdot 7$
$62 \cdot 2$
$65 \cdot 2$
$64 \cdot 7$
$64 \cdot 7$
$65 \cdot 5$
$65 \cdot 2$
$64 \cdot 3$
$62 \cdot 8$
$62 \cdot 8$

DNA competition $(\%)$

33

35

20

38

32

19

40

34

40

28

28
29

98

99

100

With Pseudomonas mendocina strain $\mathrm{CH} 20$ as the source of reference DNA, virtually total competition was obtained with DNA from three other strains of the same species, indicating a high degree of intraspecific genetic homology (Table I0). DNAs from high and low GC strains of the $P$. stutzeri-P. stanieri complex showed considerably lower, but still substantial, competition at an annealing temperature of $70^{\circ}$. Even at an annealing temperature of $80^{\circ}$, some competition by these DNAs was evident (Table 6).

Experiments with DNA from other Pseudomonas species (Table 6) at an annealing temperature of $70^{\circ}$ showed significant competition by biotypes $\mathrm{B}, \mathrm{C}, \mathrm{D}$ and $\mathrm{F}$ of $P$. fluorescens; in all these cases, however, competition fell to zero at an annealing temperature of $80^{\circ}$.

The hybridization studies accordingly suggested that Pseudomonas mendocina was a genetically uniform species, with some genetic relationship to the P. stutzeri-P. stanieri complex, and a lesser genetic relationship to some of the fluorescent pseudomonads. 


\section{DISCUSSION}

The problem of nomenspecies in the Pseudomonas stutzeri group. Within the stutzeri group, the twelve strains assigned to $P$. mendocina constituted a uniform and readily differentiable species in terms of all the criteria that we applied: DNA base composition, in vitro DNA hybridization and phenotypic properties. Judged by the same criteria, the remaining 39 strains of the group constituting the $P$. stutzeri-P. stanieri complex, emerged as a heterogeneous array which presented a difficult problem in terms of species recognition. The GC contents of the DNA of these strains ranged from 60.7 to 66.3 mole $\%$, and it was primarily because this range appeared too wide to characterize a single species, that Mandel (I966) proposed to limit the circumscription of $P$. stutzeri to strains with DNA of high GC content (about 65 mole \%) and to create a second species for strains with DNA of low GC content (about 62 mole \%). Such a specific separation could not be substantiated in terms of phenotypic differences among the 17 strains of the complex originally examined (Stanier et al. 1966), and the study of an additional 22 strains has not improved the situation. The apparently clear-cut bimodal distribution of DNA base compositions observed by Mandel (I966) in the 17 strains was not evident in the 22 newly examined strains, which showed an approximately Gaussian distribution of DNA base composition. When both sets of data were combined (see Fig. 2), the distribution of DNA base composition appeared to be polymodal, although the number of samples was still too small to permit any firm conclusion concerning the frequency distribution.

The variability of the nutritional characters of this group, evident from our original work (Stanier et al. I966) became even more marked by the inclusion of data for an additional 22 strains (Tables I, 2). A detailed analysis of nutritional data (not presented here) showed that strains of widely different GC content might be virtually indistinguishable in phenotypic respects; for example, strains 320 (62 mole \% GC) and $32 \mathrm{I}(65 \mathrm{~mole} \% \mathrm{GC})$ differed by only one of 80 nutritional characters variable within the group. We were unable to detect among our strain any clusters of differing GC content that showed sufficiently clear-cut phenotypic differences to justify their recognition as separate species.

The data on DNA hybridization with selected strains representative of the span of DNA base composition found in the complex indicated (as might be expected) that strains of similar GC content tend to show a higher level of homology with one another than with strains of different GC content. However, there were exceptions. Furthermore, all strains of the complex showed a considerable degree of genetic relatedness.

In short, we do not consider that a useful specific subdivision of this complex can be justified at present and we propose to include all strains of the $P$. stutzeri-P. stanieri complex in the single nomenspecies, $P$. stutzeri. This taxonomic treatment does not, of course, preclude the possibility of an eventual subdivision of the complex into two (or more) species, but work on a larger collection of strains, using an expanded phenotypic characterization, will undoubtedly be required to provide the necessary grounds for such a subdivision.

Problems associated with the use of flagellar insertion as a generic character. Only the polar insertion of flagella distinguishes the members of the genus Pseudomonas from the many other Gram-negative, rod-shaped eubacteria with DNA of relatively 
high GC content. However, the use of this particular structural character as a generic one raises many difficulties, both practical and theoretical. One permanently immotile organism, P. mallei, was placed in Pseudomonas on account of its close phenotypic resemblance to the polarly flagellated $P$. pseudomallei (Redfearn, Palleroni \& Stanier, 1966), and this assignment was confirmed by the demonstration of a substantial degree of nucleotide sequence homology between the two species (Rogul, Brendle, Haapala \& Alexander, I968). A different facet of the same problem is our observation on the modes of flagellar insertion characteristic of $P$. stutzeri and $P$. mendocina. Both species may possess lateral, as well as polar, flagella. Their characterization as polarly flagellated bacteria can be maintained only because the polar are distinguishable by their wavelength from the lateral flagella and predominate under certain conditions of cultivation. Comparable situations were described in Aeromonas and Chromobacterium (Rhodes, 1965). Such bacteria presumably possess two sets of genetic determinants that govern, respectively, polar and lateral flagellation, a supposition supported by Sneath's (I956) finding that the polar and lateral flagella of Chromobacterium are antigenically different, and also by the correlation between flagellar wavelength and insertion site. A bacterium in which polar and lateral flagella were of identical wavelength would, however, be characterized phenotypically as 'peritrichous' or 'degenerately peritrichous' even if it possessed two different sets of flagella subject to separate genetic control. The possibility that some apparently peritrichous Gramnegative bacteria may be related to one of the subgroups of Pseudomonas should be kept in mind by taxonomists.

Identification of denitrifying Pseudomonas spp. The early bacteriological literature on denitrification contains specific descriptions of many denitrifying organisms that are assignable to the genus Pseudomonas. No authentic strains of these species have survived, and the descriptions are so fragmentary that with the exceptions of $P$. stutzeri, $P$. aeruginosa and $P$. fluorescens it would be difficult to recognize a newly isolated strain as a representative of one of the named species. For this reason, we believe that most of the older names proposed for denitrifying pseudomonads should be treated as nomina dubia, and in this category we would place Bacillus denitrificans $\alpha$ and $\beta$ Gayon \& Dupetit (1886); Bacillus denitrificans Giltay \& Aberson (I892); Bacillus denitrificans I Burri \& Stutzer (I895); Bacillus denitrificans agilis Ampola \& Garino (r896).

The present work, coupled with that of Stanier et al. (1966) and Redfearn et al. (1966), shows that the capacity for denitrification is characteristic of five well-defined Pseudomonas species that occur in soil and water. As an aid to their identification, we have prepared a tabular key of the characters that appear to have the greatest differential value (Table $\mathrm{I}$ ).

A sixth species (Pseudomonas caryophylli) which to our knowledge has not been reported to be a soil inhabitant, but which is pathogenic for plants, is also included in the table. This vigorously denitrifying and readily recognizable organism has been characterized by Mr R. W. Ballard in our laboratory and the information shown is abstracted from his data. Some strains of another plant pathogen, P. solanacearum, also cause denitrification (Hayward, I964). We have confirmed Hayward's report, but have not yet studied this Pseudomonas species in sufficient detail to include data for it in Table II. For each phenotypic character, we list the percentage of positive strains in each species; the values for $P$. fluorescens are based on the pooled phenotypic 
data for the three denitrifying biotypes (B, C and D), and do not include data for non-denitrifying biotypes (A, E, F and G). The denitrifying biotypes of $P$. fluorescens can, in turn, be differentiated from one another in terms of additional characters (Stanier et al. 1966).

\section{Table II. Characters of highest differential value for the identification of denitrifying aerobic pseudomonads}

Figures represent the percentages of strains which are positive for each of the characters

\begin{tabular}{|c|c|c|c|c|c|c|}
\hline & $\begin{array}{l}\text { stutzeri- } \\
\text { complex } \\
\text { comp strains) }\end{array}$ & $\begin{array}{l}\text { P. } \text { mendo- } \\
\quad \text { cina } \\
\text { (1 } 2 \text { strains) }\end{array}$ & $\begin{array}{l}P \\
P . \text { aeruginosa } \\
\text { (29 strains) }\end{array}$ & $\begin{array}{l}P \text {. fluorescens } \\
\text { (biot. B, C } \\
\text { and D } \\
\text { (44 strains) }\end{array}$ & $\begin{array}{c}P . \text { pseudo- } \\
\text { mallei } \\
\text { (26 strains) }\end{array}$ & $\begin{array}{l}\text { P. caryophylli } \\
\text { (3 strains) }\end{array}$ \\
\hline $\begin{array}{l}\text { DNA (GC, } \\
\text { mole } \%)\end{array}$ & $50 \cdot 7-66 \cdot 3$ & $62 \cdot 8-64 \cdot 3$ & $66 \cdot 3-68 \cdot 3$ & $60 \cdot 3-63 \cdot 3$ & $69 \cdot 4-69 \cdot 9$ & 66 \\
\hline \multicolumn{7}{|l|}{ Structural characters } \\
\hline $\begin{array}{l}\text { Monotrichous } \\
\text { flagellation }\end{array}$ & 100 & 100 & 100 & o & 0 & 0 \\
\hline $\begin{array}{l}\text { poly- } \beta \text {-Hydroxy- } \\
\text { butyrate } \\
\text { accumulation }\end{array}$ & 0 & 0 & 0 & 0 & 100 & 100 \\
\hline \multicolumn{7}{|l|}{$\begin{array}{l}\text { Temperature } \\
\text { relationships }\end{array}$} \\
\hline Growth at $40^{\circ}$ & 100 & 100 & 100 & 0 & 100 & 100 \\
\hline Growth at $4^{\circ}$ & 0 & 0 & 0 & 100 & 0 & 0 \\
\hline \multicolumn{7}{|l|}{ Pigmentation } \\
\hline $\begin{array}{c}\text { Fluorescent } \\
\text { pigment }\end{array}$ & 0 & 0 & 72 & 84 & 0 & 0 \\
\hline Pyocyanine & 0 & 0 & 86 & 0 & 0 & 0 \\
\hline Carotenoids & 0 & 100 & 0 & 0 & 0 & 0 \\
\hline \multicolumn{7}{|l|}{$\begin{array}{l}\text { Biochemical } \\
\text { characters }\end{array}$} \\
\hline $\begin{array}{l}\text { Arginine } \\
\text { dihydrolase }\end{array}$ & 0 & 100 & 100 & 100 & 100 & 100 \\
\hline Starch hydrolysis & 98 & 0 & 0 & 0 & 100 & 0 \\
\hline $\begin{array}{l}\text { poly- } \beta \text {-Hydroxy- } \\
\text { butyrate hydrolysis }\end{array}$ & sis ${ }^{0}$ & 0 & 0 & 0 & 100 & 0 \\
\hline \multicolumn{7}{|l|}{$\begin{array}{l}\text { Nutritional } \\
\text { characters } \\
\text { Growth on: }\end{array}$} \\
\hline Xylose & 3 & 0 & 0 & 34 & 0 & IOO \\
\hline Maltose & 92 & 0 & 0 & 0 & 100 & 0 \\
\hline Saccharate & 64 & 100 & 0 & 63 & 0 & 100 \\
\hline Mannitol & 62 & 0 & 100 & 100 & 100 & 100 \\
\hline Ethylene glycol & 100 & 92 & 0 & 2 & 8 & 0 \\
\hline $\begin{array}{l}\text { 2,3-Butylene } \\
\text { glycol }\end{array}$ & 87 & 0 & 93 & 73 & 0 & 100 \\
\hline Geraniol & 0 & 100 & 100 & 0 & 0 & 0 \\
\hline Azelate & 90 & 0 & 97 & 20 & 88 & 0 \\
\hline Levulinate & 5 & 92 & 100 & 20 & 92 & 0 \\
\hline Glycollate & 90 & 100 & 0 & 2 & 0 & 100 \\
\hline Serine & 10 & 100 & 14 & 80 & 96 & 100 \\
\hline Arginine & 0 & 100 & 100 & 100 & 100 & 100 \\
\hline Histidine & 0 & 100 & 100 & 9I & 100 & 100 \\
\hline Betaine & 5 & 100 & 100 & 100 & 100 & 100 \\
\hline Sarcosine & 3 & 100 & 90 & 84 & 88 & 0 \\
\hline
\end{tabular}



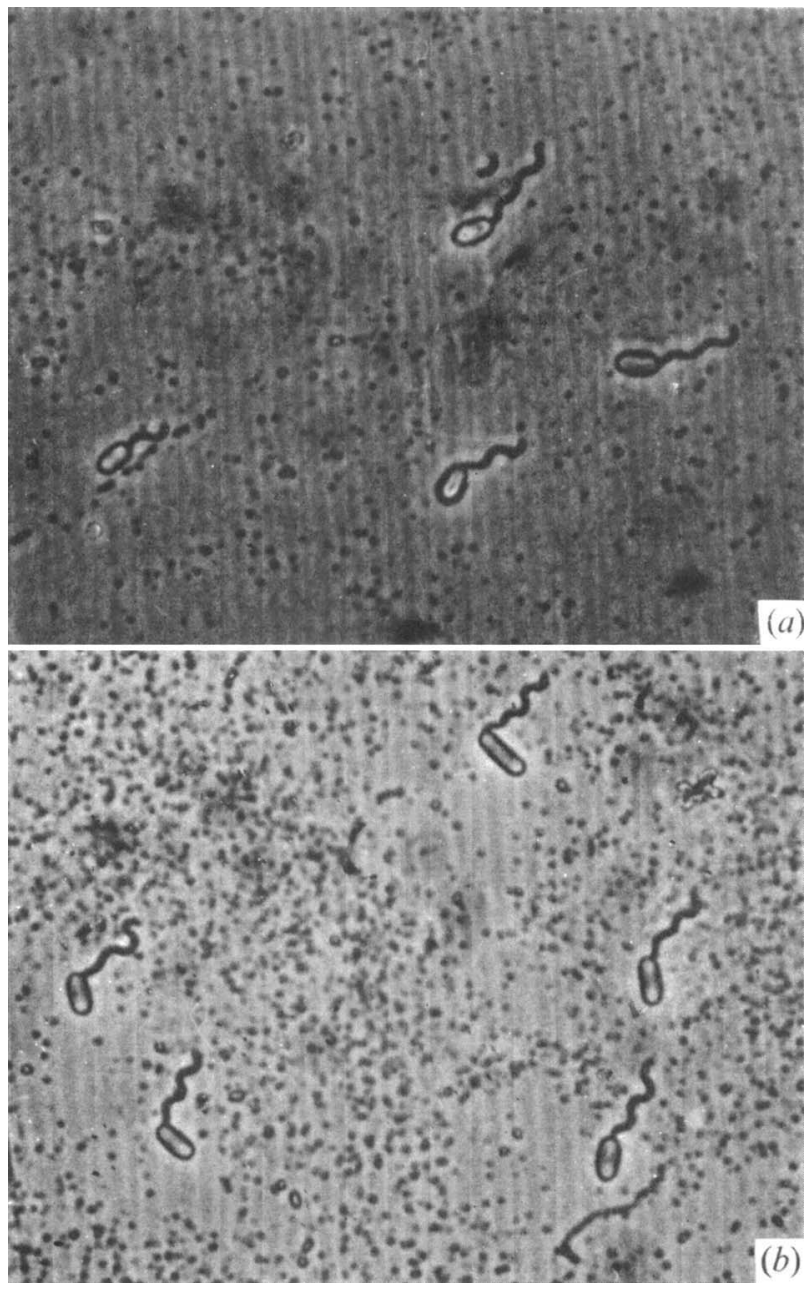

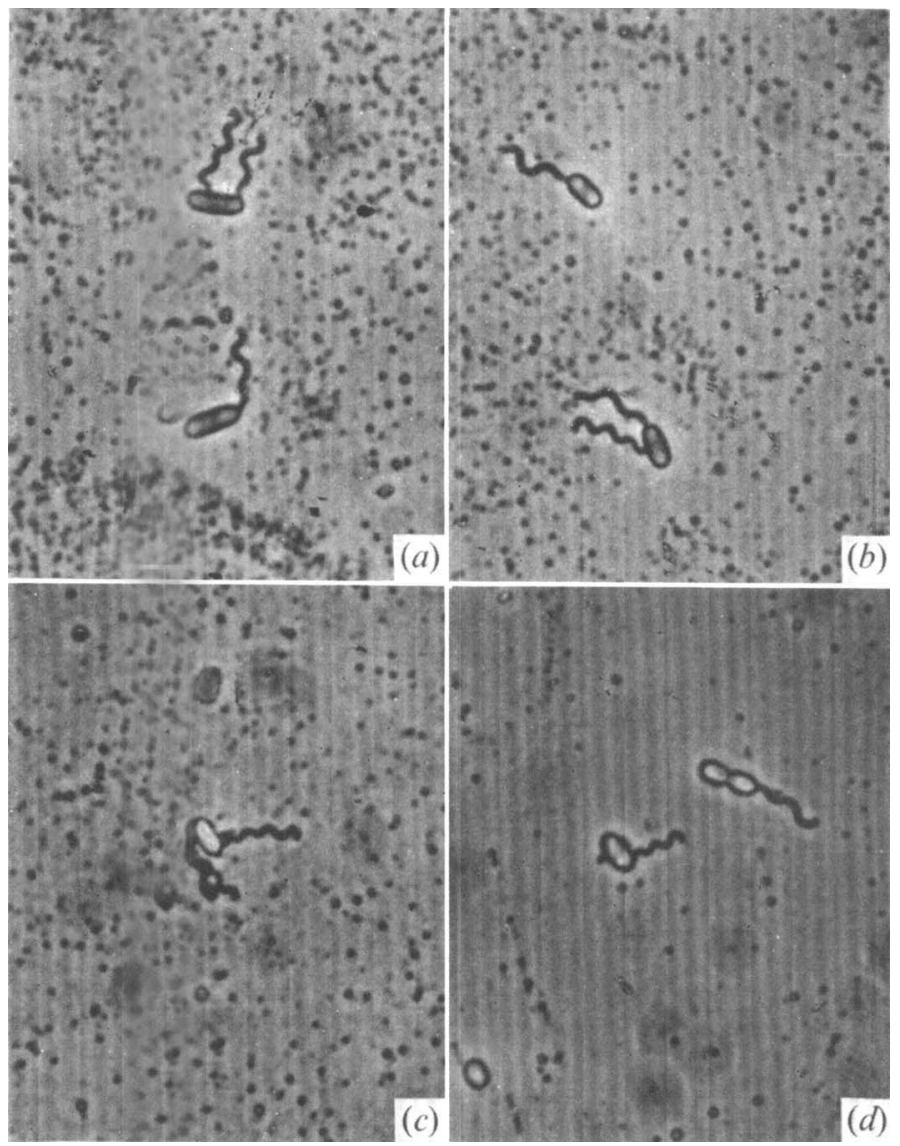

N. J. PALLERONI AND OTHERS 
This work was supported in part by grants-in-aid from the National Institutes of Health (AI-1808) and the National Science Foundation (GB-5748) to M. Doudoroff and $\mathrm{R}$. Y. Stanier, respectively. We are grateful to Mr R. W. Ballard for assistance in the DNA hybridization studies.

\section{REFERENCES}

Ampola, G. \& Garino, E. (1896). Ueber die Denitrifikation. Zentrablatt für Bakteriologie, Parasitenkunde, Infektionskrankheiten und Hygiene (Abteilung II) 2, 670.

Ballard, R. W., Palleroni, N. J., Doudoroff, M., Stanier, R. Y. \& Mandel, M. (i970). Taxonomy of the aerobic pseudomonads: Pseudomonas cepacia, P. marginata, P. alliicola and P. caryophylli. Journal of General Microbiology 6o, 199.

Baumann, P., Doudoroff, M. \& Stanier, R. Y. (I968). A Study of the Moraxella Group. II. Oxidase-negative species (genus Acinetobacter). Journal of Bacteriology 95, 1520.

BURRI, R. \& STUTZER, A. (I895). Über Nitrat zerstörende Bakterien und den durch dieselben bedingten Stickstoffverlust. Zentralblatt für Bakteriologie, Parasitenkunde, Infektionskrankheiten und Hygiene (Abteilung II) 1, 257, 350, 392, 422.

Gayon, U. \& DuPETrT, G. (I 886). Recherches sur la Réduction des Nitrates par les Infiniments Petits. Nancy: Berger-Levrault \& Cie.

Giltay, E. \& Aberson, G. (I 892). Recherches sur une mode de dénitrification et sur le schizomycète qui la produit. Archives Néerlandaises des Sciences Exactes et Naturelles 25, 34I.

Hayward, A.C. (1964). Characteristics of Pseudomonas solanacearum. Journal of Applied Bacteriology $27,265$.

Johnson, J. L. \& ORDAL, E. J. (1968). Deoxyribonucleic acid homology in bacterial taxonomy: effect of incubation temperature on reaction specificity. Journal of Bacteriology 95, 893.

Lehmann, K. B. \& Neumann, R. (1896). Atlas und Grundriss der Bakteriologie und Lehrbuch der Speciellen Bakteriologischen Diagnostik. München: J. F. Lehmann.

MANDEL, M. (1966). Deoxyribonucleic acid base composition in the genus Pseudomonas. Journal of General Microbiology 43, 273.

MARMUR, J. (I96I). A procedure for the isolation of deoxyribonucleic acid from micro-organisms. Journal of Molecular Biology 3, 208.

van Niel, C. B. \& Allen, M. B. (1952). A note on Pseudomonas stutzeri. Journal of Bacteriology 64, 413 .

Redfearn, M. S., Palleroni, N. J. \& Stanier, R. Y. (1966). A comparative study of Pseudomonas pseudomallei and Bacillus mallei. Journal of General Microbiology 43, 293.

RHODEs, M. E. (1965). Flagellation as a criterion for the classification of bacteria. Bacteriological Reviews 29, 442.

Rogul, M., Brendle, J., Haapala, D. K. \& Alexander, A. D. (I968). DNA homologies among Pseudomonas pseudomallei, Actinobacillus mallei and phenotypically similar organisms. Bacteriological Proceedings p. 19.

SNEATH, P. H. A. (1956). The change from polar to peritrichous flagellation in Chromobacterium species. Journal of General Microbiology 15, 99.

Stanier, R. Y., Palleron, N. J. \& Doudoroff, M. (1966). The aerobic pseudomonads: a taxonomic study. Journal of General Microbiology 43, I59.

\section{EXPLANATION OF PLATES}

\section{Plate I}

Flagella stain (Leifson's method) of Pseudomonas stutzeri, strain 227(a), and of $P$. mendocina, strain CH IIO $(b) . \times 2000$.

Plate 2

Flagella stain (Leifson's method) showing cells with lateral flagella of short wavelength: Pseudomonas mendocina, strain $\mathrm{CH}$ I IO $(a)$ and $(b) ; P$. stutzeri, strain $319(c)$, and P. stutzeri, strain $227(d)$. 